\title{
Quality Assessment of Selected Vitamin C Tablets Sold at Bridge Head Market, Onitsha
}

\author{
Kingsley Ogemdi Iwuozor \\ Department of Pure and Industrial Chemistry, Nnamdi Azikiwe University Awka, Awka, Nigeria \\ Email address: \\ unizik.ich@gmail.com

\section{To cite this article:} \\ Kingsley Ogemdi Iwuozor. Quality Assessment of Selected Vitamin C Tablets Sold at Bridge Head Market, Onitsha. Chemical and \\ Biomolecular Engineering. Vol. 3, No. 3, 2018, pp. 47-50. doi: 10.11648/j.cbe.20180303.15
}

Received: September 3, 2018; Accepted: September 19, 2018; Published: October 31, 2018

\begin{abstract}
Due to the importance of ascorbic acid in humans, qualitative and quantitative evaluation of ascorbic acid has gained a significant increase in several areas of analytical chemistry such as pharmaceutical analysis. Several analytical methods have been developed. Most of these methods are laborious and some require much reagents that may be either not readily available or are expensive. There is an influx of counterfeit drugs in the market and due to this, two questions come up; are we underdozed? Or overdozed? This is a research on the quality of selected brands of Vitamin C tablets. In this research work, five brands of Vitamin $\mathrm{C}$ tablets were purchased at Bridge head market, Onitsha and were analyzed for their percentage content of Ascorbic Acid (active pharmaceutical product), their average percentage friability, disintegration time and hardness using a UV/Vis spectrophotometer, friabilator, disintegration tester and hardness tester. The results showed that they all passed the hardness and disintegration time test. Samples 1, 3, 4, and 5 failed the test for the percentage content of Ascorbic acid; Sample 2 failed the friability test. Sample 2 has proven to have the highest quality and would be able to enact action faster since it has the highest quantity of Ascorbic acid that will be disintegrated at any time and this also means that it will be absorbed into the blood stream faster.
\end{abstract}

Keywords: Friability, Disintegration, Ascorbic Acid, UV Spectrophotometer

\section{Introduction}

Vitamin $\mathrm{C}$ otherwise known as ascorbic acid is a water soluble vitamin that is naturally present in some foods, added to others and taken as a dietary supplement. Though it is derived from glucose, humans and some other primates like guinea pigs, teleost, fishes, bats and birds cannot synthesize it invivo due to the genetic mutation that prevents them from synthesizing L-gluconolactone oxidase enzyme, which converts glucose to ascorbic acid. Vitamin $\mathrm{C}$ can be synthesized by some other animals like dogs, goats, sheep, etc. [1]. Vitamin C or ascorbic acid is widely present in many biological systems and in multivitamin preparations. Ascorbic acid is commonly used to supplement inadequate dietary intake and as an antioxidant [2].

Vitamin $\mathrm{C}$ is an important component of a healthy diet. Its history revolves around that of the human scurvy disease; a severe form of vitamin $\mathrm{C}$ deficiency, probably the first human sickness to be recognized as a deficiency disease. Its symptoms includes exhaustion, massive haemorrhaging of flesh and gums, general weakness and diarrhoea. Presently, it is rare to be seriously deficient of vitamin $\mathrm{C}$, although evidence suggests that many people may have low levels of Vitamin C. Smoking cigarettes lowers the amount of vitamin $\mathrm{C}$ in the body. Smokers are therefore at a higher risk of its deficiency [3]. Vitamin $\mathrm{C}$ is needed for the growth and repair of tissues in all parts of the body. It helps the body make collagen; an important protein used to make skin, cartilage, tendons, ligaments and blood vessels. It is also needed for healing of wounds and maintenance of bones and teeth [4].

Laboratory studies have confirmed that high dosing with vitamin $\mathrm{C}$ is cytotoxic to wide range of cancer cell lines and that it boots the anti-cancer activities of several common chemotherapy drugs. In animal models (rats), intra-venous vitamin $\mathrm{C}$ has been shown to significantly decrease growth rates of liver, ovarian, pancreatic and globlastoma tumors with dosages easily achievable in humans [5]. 


\section{Materials and Methods}

\subsection{Sample Collection}

Five (5) samples of Vitamin C 500mg tablets were obtained at drug market, Bridge head. The NAFDAC registration number, batch number, manufacturing and expiry dates were properly checked before purchasing.

\subsection{Experimental Procedures}

\subsubsection{Determination of Percentage Content}

The average weight of tablets from each sample was determined by weighing (20) tablets and dividing the result by twenty, then the tablets were then crushed using a clean pestle and mortar (i.e. for each sample). For each sample, powder containing $0.025 \mathrm{~g}(250 \mathrm{mg})$ of vitamin $\mathrm{C}$ was accurately weighed and transferred into different $1000 \mathrm{ml}$ beakers. All the five samples were labeled using a pen and a masking tape. To each beaker, $100 \mathrm{ml}$ of distilled water was added, and shaken for 15 minutes with the aid of a magnetic stirrer to dissolve the drug molecule. After shaking, the volume was made up to the $200 \mathrm{ml}$ mark with distilled water. The mixture in each beaker was then mixed well and filtered through a filter paper into clean beakers. From the filtrate, $2 \mathrm{ml}$ of the resulting solution was transferred into a $25 \mathrm{ml}$ conical flask then $2 \mathrm{ml}$ of Sulphuric acid was added followed by the addition of $4 \mathrm{ml}$ ammonium Molybdate tetrahydrate (the mixture turns to light blue which deepens on standing) and then allowed to stand for 60 minutes, this was made up with distilled water.

The UV-Visible Spectrophotometer was put at zero with the aid of the blank solution that was prepared the same way as the sample solution with the exclusion of the addition of the sample at $650 \mathrm{~nm}$. The absorbance of each sample was determined at $650 \mathrm{~nm}$, by putting small amount of the sample into a cuvette and the cuvette was put into the machine. The same procedure was repeated for the standard using $250 \mathrm{mg}$ of the powdered standard and the absorbance determined which was used to calculate the percentage content of Ascorbic acid in each sample.

$$
\text { Weight of Sample }(\mathrm{g})=\frac{\text { Weight of standard } \times \text { Average weight }}{\text { Label Claim }}
$$

$$
\begin{gathered}
\text { Theoretical yield }=\frac{\text { Sample absorbance } \times \text { Weight of standard used } \times \text { Average weight of sample } \times 1000}{\text { Standard absorbance } \times \text { Weight of sample used }} \\
\% \text { Assay }=\frac{\text { Theoretical yield } \times 100}{\text { Label claim }}
\end{gathered}
$$

\subsubsection{Determination of Disintegration Time}

The two $1000 \mathrm{ml}$ glass beakers of the disintegration time machine was filled to the $900 \mathrm{ml}$ mark with warm water and re-inserted into the machine. Six tablets of each sample were selected and placed in each of the cylindrical tubes of the basket and the disc was placed on the tablets. The baskets were then placed gently into the glass beakers filled with water and it was then hooked unto the machine. The machine was then turned on and regulated at a temperature of $37^{\circ} \mathrm{C}$ and allowed to run as it dips the basket in and out of the water. The time taken to break each tablet into small particles and pass out through the mesh was recorded.

\subsubsection{Determination of Average Percentage Friability}

Ten tablets for each sample were initially dusted, weighed and the mass recorded. The tablets were then transferred into the left wing of the friabilator. Another ten tablets for the same sample were also dusted, weighed and its mass also recorded. The tablets were then transferred into the right wing of the friabilator. The friabilator was operated at and subjected to its tumbling actions for 100 revolutions. After the revolutions, the tablets on both wings were removed, dusted and later reweighed. This served as the final reading for both the left and right wing. From these readings, the percentage loss of each samples were calculated as well as the Average percentage friability.

$$
\begin{aligned}
& \qquad \% \text { loss }=\frac{\text { Initial mass }- \text { Final mass } \times 100}{\text { Initial mass } 1} \\
& \text { Average Friability }=\frac{\% \text { loss of friability (left) }+\% \text { loss of friability (right) }}{2}
\end{aligned}
$$

\subsubsection{Determination of Tablet Hardness}

The screw knob of the Monsanto hardness tester was rotated in an anti-clockwise fashion to draw-in the moving jaw of the machine. A tablet from each sample was then fixed between the fixed and moving jaw. Then the screw knob was rotated in a clockwise fashion until the moving jaw touches the tablet that is now firmly fixed between the fixed and moving jaw. The screw knob is continuously rotated in the clockwise fashion until the tablet breaks. The reading at this point is taken with the aid of the indicator in the scale. 


\section{Results}

Table 1. Table showing the Samples and their characteristics.

\begin{tabular}{llll}
\hline S/N & SAMPLES & Mfd. Date & Exp. Date \\
\hline 1 & Sample 1 & $03 / 17$ & $02 / 20$ \\
2 & Sample 2 & $08 / 17$ & $07 / 20$ \\
3 & Sample 3 & $04 / 17$ & $03 / 20$ \\
4 & Sample 4 & $07 / 17$ & $06 / 21$ \\
5 & Sample 5 & $03 / 17$ & $02 / 20$ \\
\hline
\end{tabular}

Table 2. Result of the Percentage Content of Ascorbic acid.

\begin{tabular}{llllllll}
\hline SAMPLES & Mfd. Date & Exp. Date & Label claim & $\begin{array}{l}\text { Average Weight } \\
\text { of Sample }\end{array}$ & $\begin{array}{l}\text { Weight of } \\
\text { Sample Used }\end{array}$ & $\begin{array}{l}\text { Sample } \\
\text { Absorbance }\end{array}$ & $\begin{array}{l}\text { \% assay result } \\
\text { Sample 1 }\end{array}$ \\
\hline $03 / 17$ & $02 / 20$ & $500 \mathrm{mg}$ & $0.5244 \mathrm{~g}$ & $0.026 \mathrm{~g}$ & 0.2239 & $88.58 \%$ \\
Sample 2 & $08 / 17$ & $07 / 20$ & $500 \mathrm{mg}$ & $0.5032 \mathrm{~g}$ & $0.025 \mathrm{~g}$ & 0.2452 & $96.81 \%$ \\
Sample 3 & $04 / 17$ & $03 / 20$ & $500 \mathrm{mg}$ & $0.5556 \mathrm{~g}$ & $0.028 \mathrm{~g}$ & 0.2326 & $90.53 \%$ \\
Sample 4 & $07 / 17$ & $06 / 21$ & $500 \mathrm{mg}$ & $0.5537 \mathrm{~g}$ & $0.028 \mathrm{~g}$ & 0.2236 & $86.73 \%$ \\
Sample 5 & $03 / 17$ & $02 / 20$ & $500 \mathrm{mg}$ & $0.5234 \mathrm{~g}$ & $0.026 \mathrm{~g}$ & 0.2319 & $91.57 \%$ \\
\hline
\end{tabular}

The Absorbance of the standard $=0.2549$

The Weight of the standard used $=0.025 \mathrm{~g}$

Table 3. Result of the average friability of the Vitamin C tablets.

\begin{tabular}{|c|c|c|c|c|c|c|c|c|c|}
\hline \multirow{2}{*}{$\begin{array}{l}\text { SAMPLES } \\
\text { Sample } 1\end{array}$} & \multirow{2}{*}{$\begin{array}{l}\text { Mfd. Date } \\
03 / 17\end{array}$} & \multirow{2}{*}{$\begin{array}{l}\text { Exp. Date } \\
02 / 20\end{array}$} & \multicolumn{3}{|c|}{$\begin{array}{l}\text { FRIABILITY(LEFT) } \\
\text { InitialFinal \% Loss } \\
\end{array}$} & \multicolumn{3}{|c|}{$\begin{array}{l}\text { FRIABILITY(RIGHT) } \\
\text { InitialFinal \% Loss } \\
\end{array}$} & \multirow{2}{*}{$\begin{array}{l}\text { AVERAGE } \\
\text { FRIABILITY } \\
0.871 \%\end{array}$} \\
\hline & & & $5.293 \mathrm{~g}$ & 5.238 & 1.039 & 5.122 & 5.086 & 0.703 & \\
\hline Sample 2 & $08 / 17$ & $07 / 20$ & $5.481 \mathrm{~g}$ & 5.393 & 1.606 & 5.582 & 5.555 & 0.484 & $1.045 \%$ \\
\hline Sample 3 & $04 / 17$ & $03 / 20$ & $5.832 \mathrm{~g}$ & 5.785 & 0.806 & 5.902 & 5.865 & 0.627 & $0.717 \%$ \\
\hline Sample 4 & $07 / 17$ & $06 / 21$ & $5.732 \mathrm{~g}$ & 5.709 & 0.401 & 5.843 & 5.816 & 0.462 & $0.432 \%$ \\
\hline Sample 5 & $03 / 17$ & $02 / 20$ & $5.522 \mathrm{~g}$ & 5.498 & 0.435 & 5.781 & 5.732 & 0.848 & $0.642 \%$ \\
\hline
\end{tabular}

Table 4. Result of the Disintegration Time of the Vitamin C tablets.

\begin{tabular}{llll}
\hline SAMPLES & Mfd. Date & Exp. Date & DISINTEGRATION TIME \\
\hline Sample 1 & $03 / 17$ & $02 / 20$ & 4 minutes, 08 seconds \\
Sample 2 & $08 / 17$ & $07 / 20$ & 3 minutes, 12 seconds \\
Sample 3 & $04 / 17$ & $03 / 20$ & 2 minute, 28 seconds \\
Sample 4 & $06 / 21$ & 2 minutes, 26 seconds \\
Sample 5 & $07 / 17$ & $02 / 20$ & 10 minutes, 26 seconds \\
\hline
\end{tabular}

Table 5. Result on the Hardness test of the Vitamin C tablets.

\begin{tabular}{llll}
\hline SAMPLES & Mfd. Date & Exp. Date & HARDNESS \\
\hline Sample 1 & $03 / 17$ & $02 / 20$ & $4.7 \mathrm{kgf}$ \\
Sample 2 & $08 / 17$ & $07 / 20$ & $5.0 \mathrm{kgf}$ \\
Sample 3 & $04 / 17$ & $03 / 20$ & $5.5 \mathrm{kgf}$ \\
Sample 4 & $07 / 17$ & $06 / 21$ & $5.8 \mathrm{kgf}$ \\
Sample 5 & $02 / 20$ & $6.5 \mathrm{kgf}$ \\
\hline
\end{tabular}

\section{Discussion}

All the brands of tablets and syrups used were within their shelf-lives as at the time of study. The result of percentage content is in table 2. According to British Pharmacopoeia (B. P.), a Vitamin C tablet should contain not less than $95 \%$ and not more than $107.5 \%$ of Ascorbic acid. From the result in Table 2, the percentage of Ascorbic acid in Samples 1, 3, 4, and 5 were below the required specification (i.e. they failed and any patient consuming it would be taking an under-dosage of the drug), Only the percentage of Ascorbic acid in Sample 1 was within the required specification.

According to United State Pharmacopoeia (U.S.P.), not more than $1 \%$ of the initial mass of both coated and uncoated tablets should be lost on friability or the drug would not be able to withstand stress and would disintegrate faster. From the result on table 3, which shows the average \% friability of the Vitamin $\mathrm{C}$ tablets, the Average \% Friability of the Vitamin $\mathrm{C}$ tablets in all the five samples except Sample 2 $(1.045 \%)$ is in agreement with the U. S. P. tolerance limit. This means that Sample 2 would not be able to withstand the tensile stress which is attributed to the insufficient binders used in its production. Among those that passed, Sample 1 had the highest Average \% Friability of Ascorbic acid tablets 
$(0.871 \%)$ and Sample $4(0.432 \%)$ has the lowest Average \% Friability of the Vitamin $\mathrm{C}$ tablets.

Table 4 shows the disintegration time test. According to the British pharmacopoeia (1980), uncoated tablets must disintegrate within 15 minutes. Similarly, all the brands complied with the official specification of less than $15 \mathrm{~min}$ as disintegration time for uncoated tablets (Table 4). Ability of these brands to disintegrate within this time limit is a good indication that the tablets will disintegrate in the gastrointestinal tract and release their contents into the system. The B. P. specifies that not less than $70 \% \mathrm{w} / \mathrm{w}$ labeled content should dissolve at 45 minutes. From the result in table 4, all the samples passed the test. Sample 4 has the lowest disintegration time of 2 minute, 26 seconds while Sample 5 has the highest disintegration time of 10 minutes, 26 seconds

The acceptable range of hardness or crushing strength of tablet is 4 to $7 \mathrm{kgf}$ (kilogram of force). From the result in table 5, all the samples passed the test. Sample 1 has the lowest Hardness of $4.2 \mathrm{kgf}$ while Sample 5 has the highest Hardness of $6.5 \mathrm{kgf}$. This means that all the samples have the capability to withstand mechanical shocks during handling in manufacturing, packaging and shipping. This also means that those that have higher hardness values have more binders which are used to increase the mechanical strength of the tablet.

\section{Conclusion}

In conclusion, Samples 1, 3, 4, and 5 Vitamin C tablets failed the assay test while Sample 2 failed the friability test even though it passed the assay test. Among the 500mg tablets that passed, Sample 3 has proven to have the highest quality and would be able to enact action faster since it has the highest quantity of Ascorbic acid that will be disintegrated at any time and this also means that it will be absorbed into the blood stream faster. The disintegration time and dissolution rates have direct bearing on the bioavailability profile of tablet dosage forms as it can be used to predict the drug release pattern in vivo. From the analytical result obtained, it is recommended that;

(1) Drug Survey should be carried out from time to time by the Drug Regulatory Agencies to be able reduce the consumption of inadequate or counterfeit drugs for the benefit of public health.

(2) The pharmaceutical industries should adhere to the official standards such as B. P, U. S. P and E. P. for the production of drugs.

(3) Quality control personnel must be a trained and qualified individual who will assist in all stages of production by effecting good manufacturing practices in terms of checking, monitoring, evaluating and documenting for safe and efficacious drugs.

\section{References}

[1] Akinyandenu, O. (2013). Counterfeit drugs in Nigeria: A threat to public health. African Journal of Pharmacy andPharmacology. 7(36), pp. 2571-2576.

[2] Bajaj, S. S and Gupta, A. K. (2012). Introduction to pharmaceutics - II, CBS Publishers and Distributors, India, pp52-53.

[3] Eichie, F. E. and Kudehinbu, A. O. (2009). Effect of particle size of granules on some mechanical properties of paracetamol tablets. African Journal of Biotechnology. 8(21), pp. 5913-5916.

[4] Finkel, R., Cubeddu, L. X. and Clark, M. A. (2009). Pharmacology, $4^{\text {th }}$ edition, Lippincott Williams and Wilkins, U.S.A, pp 20-24,502,510.

[5] Gangwar, S., Singh, S., Garg, G., Garg, V., \& Sharma, P., K. (2010). To Compare the Disintegrating Property Of Papaya Starch And Sago Starch In Paracetamol Tablets. International Journal of Pharmacy and Pharmaceutical Sciences. 2(2), pp. 148-151.

[6] Gupta, L. C., Gupta, A. and Gupta, K. (2009). Dictionary of pharmacy, Virender Kumar, India, pp207-208.

[7] James, M. R., Lionel, D. L., Timothy, G. K. and Albert, F. (2008). A Text book of Clinical Pharmacology and Therapeutics, Hodder Arnold, Britain, pp24-30.

[8] Jones, M. and Carey, F., (2012). Organic Chemistry, $5^{\text {th }}$ edition, Norton publisher, London, Pp 879-896.

[9] Katzung, B. G. (2007). Basic and Clinical Pharmacology, MC Graw-Hill Companies, U.S.A, pp50-60.

[10] Lacy, F. L., Armstrong, L. L., Goldman, P. M. and Leonard, L. L. (2011). Drug Information Handbook, Lexi-Comp Inc, USA, pp25-27.

[11] Ngwuluka, N. C., Idiakhoa, B. A, Nep, E. I., Ogaji, I. and Okafor, I. S. (2010). Formulation and evaluation of paracetamol tablets manufactured using the dried fruit of Phoenix dactylifera Linn as an Excipient, Research In Pharmaceutical Biotechnology;2(3), pp.25-32.

[12] Sakai, J. B. (2009) Practical Pharmacology for Pharmacy technicians, Lippincott Williams and Wilkins, U.S.A. pp669673.

[13] The British pharmacopoeia (2013). Pharmaceutical press. London, pp326,799-800

[14] The pharmaceutical codex, (2013). Pharmaceutical press. London, pp638-640

[15] Tripathi, K. D. (2014). Essentials of Medical Pharmacology, Jaypee Brothers Medical publishers Ltd, India, pp11-23

[16] United States Pharmacopoeia (2012). The Official Compendia of Standards, volume II, pp1269. 